\title{
A CONDUÇÃO EFICIENTE DE UM PROCESSO ADMINISTRATIVO DISCIPLINAR COMO APOIO ÀGESTÃO PÚBLICA
}

\author{
Fernanda Doria, Francislaine de Almeida Coimbra Strasser, Fábio Ferreira Morong \\ Universidade do Oeste Paulista - UNOESTE. E-mail: fer.silvadoria123@gmail.com
}

\section{RESUMO}

O artigo sob a égide de estudos visa elucidar questões pertinentes ao Processo Administrativo Disciplinar (PAD), e a disparidade existente com o instrumento da Sindicância, de modo a conceituá-los como esferas conexas e contrapostas entre si. Por conseguinte, a resolução do projeto caracteriza-se na busca de uma análise de eficácia, importância e fundamento jurídico dos referidos instrumentos administrativos, considerando as legislações vigentes, jurisprudências e doutrinas correspondentes, de forma a evitar formações de processos que apresentem vícios e nulidades, sendo-os denominados desnecessários à gestão pública. Foi possível obter por desígnio que o dever dos gestores em apurar as infrações disciplinares, transcende a mera abertura do procedimento administrativo adequado. Isso porque além de estarem associados à gestão pública, o operador deve guardar uma conduta em observância aos princípios constitucionais, na abertura e julgamentos de procedimentos desnecessários. De modo concludente, constata-se que não pode a Administração Pública na qualidade de empregadora, desonerar faltas funcionais praticadas por seus servidores, ainda que seja de enorme qualidade sua expressão trabalhista. $O$ entendimento resultante promove, por fim, a abertura de tais procedimentos somente quando embasado elementos que tornem imprescindíveis sua continuidade e sua finalização útil, a fim de satisfazer as pretensões e os desideratos da Administração. Destarte, para fomentar o estudo, o preceito aplicado será o método dedutivo e a hermenêutica dialética, partindo de uma generalização para uma questão particularizada, com o intuito de considerar as práticas sociais, no âmbito Administrativo-Jurídico, a fim de explorar os meios que se valem a Administração, para estigmatizar seus administrados.

Palavras-Chave: Processo Administrativo Disciplinar. Sindicância. Infrações. Fundamento Jurídico. Servidor Público.

\section{EFFICIENT CONDUCT OF A DISCIPLINARY ADMINISTRATIVE PROCESS AS SUPPORT TO PUBLIC MANAGEMENT}

\begin{abstract}
The article under the auspices of studies aims to elucidate issues pertinent to the Disciplinary Administrative Process (PAD), and an existing disparity with the Inquiry instrument, in order to conceptualize them as connected and opposing spheres. Therefore, the resolution of the project fails to comply with the search for an analysis of the effectiveness, importance and legal basis of the administrative instruments, considering the current legislation, jurisprudence and corresponding doctrines, in order to avoid formation of processes that present defects and nullities, being -the so-called unnecessary to public management. It was possible to obtain by design that the duty of managers in investigating disciplinary infractions, transcends the mere opening of the appropriate administrative procedure. This is because in addition to being associated with public management, the operator must maintain conduct in compliance with constitutional principles, in opening and judging unnecessary procedures. In a conclusive way, it appears that the Public Administration cannot, as an employer, relieve available absences practiced by its employees, even though its labor expression is of enormous quality. The resulting understanding promotes, finally, the opening of such procedures only when based on elements that make their continuity and useful completion essential, in order to satisfy Management's aspirations and desires. Thus, to encourage the study, the applied precept will be the deductive method and the dialectical hermeneutics, starting from a
\end{abstract}


generalization to a particularized question, with the intention of considering the social practices, in the Administrative-Legal scope, in order to explore the means that use the Administration, to stigmatize its administrators.

Keywords: Disciplinary Administrative Process. Inquiry. Infractions. Legal Basis. Public Server.

\section{INTRODUÇÃO}

O sistema disciplinar confere à Administração Pública poderes para apurar infrações e aplicar penalidades em relação àqueles sujeitos e à disciplina interna da União, pela sujeição/subordinação que apresentam para com a Administração.

Os instrumentos destinados a apurar tais penalidades, desde que obedecido o devido processo legal, caracterizam-se como processo administrativo disciplinar e sindicância (LIMA, 1994).

Conforme Bacellar Filho (2013), a autoridade que tiver ciência da irregularidade cometida noserviço público é obrigada a apurar, logo em seguida, mediante Sindicância ou Processo Administrativo Disciplinar - PAD, sob pena de responder por improbidade administrativa, consistindo em retardar ou deixar de praticar indevidamente ato de ofício, nos termos do artigo 11 , inciso II, da Lei no 8.429/1992, (BRASIL, 1992).

Logo, em razão da competente gestão pública que é o objetivo a ser alcançado pelas autoridades competentes para apuração dessas penalidades, faz-se mister ressaltar que o PAD seja executado respeitando os direitos e garantias daqueles que estão sendo acusados no processo administrativo disciplinar (sujeitos passivos). Daí que, os princípios do contraditório e ampla defesa, bem como do devido processo legal se fundem para demonstrar à sociedade que a Administração é idônea e justa, com o respeito a todos os direitos e garantias fundamentais, cuja força motriz é a dignidade da pessoa humana.

Não obstante, verifica-se uma grande problemática no campo da Administração Pública referente à incapacidade que a maioria dos profissionais apresentam para avaliar determinados processos disciplinares, mormente quando o servidor, cumulando duas funções, comete falta grave em uma delas. A relação dos servidores, pecam no profissionalismo, o que contradiz com todos os princípios constitucionais e administrativos, por resultarem em omissões na apuração das faltas graves ou no excesso de rigorismo no momento da apuração, aplicando penas descabidas.

A partir dos elementos supracitados, busca-se estudar a tamanha importância de analisar e proferir a exata diferenciação referente ao Processo Administrativo Disciplinar e a Sindicância, ainda que pouco explorados, frente ao Direito Administrativo Constitucional, em diálogo com os princípios constitucionais da razoabilidade e proporcionalidade para os casos trazidos a julgamento pela Administração Pública. Ademais, o desenvolvimento do trabalho será efetivado por meio de legislações correspondentes, doutrinas e jurisprudências relevantes, aplicando-se a hermenêutica jurídica correspondente.

\section{DELINEAMENTO METODOLÓGICO}

A ordenação aplicada será o método dedutivo, emanado de uma generalização para uma questão mais particularizada.

Segundo Gil (2008), este meio de pesquisa parte de princípios reconhecidos como verdadeiros e indiscutíveis, possibilitando chegar a conclusões em virtude unicamente de sua lógica. É o segmento proposto pelos racionalistas, segundo os quais só a razão é capaz de levar ao conhecimento verdadeiro, que decorre de princípios a priori evidentes e irrecusáveis. A abordagem define-se pela hermenêutica-dialética. A hermenêutica pode ser considerada como uma técnica que compreende textos, em sentido amplo: biografia, livro, artigo, narrativa, documento, pareceres, legislações, jurisprudências, teses e dissertações. Por sua vez, a abordagem dialética procura nos fatos os núcleos obscuros e contraditórios, para realizar críticas em relação aos mesmos. 0 pensamento dialético compreende que a análise dos significados deve ser realizada, considerando as práticas sociais e ressaltando o condicionamento histórico das falas (MINAYO, 2010).

\section{ASSIMETRIA ENTRE SINDICÂNCIA E PROCESSO ADMINISTRATIVO DISCIPLINAR}

De acordo com Mauro Roberto Gomes 
de Mattos (2012), a lei que instituiu o Regime Jurídico dos Servidores da Administração Federal estabelece diferentes fases e etapas de apuração do ato infracional cometido pelo funcionário sujeito à Administração Pública, para então definir o processo disciplinar necessário que pode ocasionar a perda do respectivo cargo, advertências e, até mesmo, o arquivamento do processo.

O Poder Judiciário pode reaver o processo administrativo, tão somente no que se refere à sanção imposta; se está ou não de acordo com o devido processo legal, isto é, se todas as formalidades procedimentais foram atendidas, de tal sorte que todas essas alegações devem ser expostas de forma clara pela parte, que sofreu o prejuízo. Portanto, eventual nulidade no processo administrativo exige a respectiva comprovação do prejuízo sofrido. Assim defende Celso Antônio Bandeira de Mello (2014, p. 979):

Assim como ao judiciário compete fulminar todo comportamento ilegítimo da administração que apareça como frontal violação da ordem jurídica, compete-lhe, igualmente, fulminar qualquer comportamento administrativo que, a pretexto de exercer apreciação ou decisão discricionária, ultrapassar as fronteiras dela, isto é, desbordar dos limites de liberdade que the assistiam, violando, por tal modo, os ditames normativos que assinalam os confins da liberdade discricionária.

Significa apontar que se for aplicada a pena de demissão pela autoridade processante numa sindicância, por exemplo, seguramente esse funcionário judicializará a pena de demissão aplicada de forma errônea, sendo que se essa autoridade tivesse aberto o processo administrativo disciplinar, que seria o correto para a pena de demissão, evitaria mais um caso envolvente da apreciação judicial, além de ter oportunizado ao servidor o meio processual correto para sedefender.

Isso porque existem dois instrumentos destinados a apurar a existência de irregularidadese a inocência ou culpabilidade do servidor por infração praticada no exercício de suas atribuições que tenha relação com as atribuições do cargo: Sindicância e Processo Administrativo Disciplinar. Este (processo administrativo) só será instaurado se já apontar um agente infrator, sendo esse definido como acusado.

Assim, é possível a instauração do PAD independentemente de sindicância, quando houver confissão lógica ou forem evidentes a autoria e a materialidade da infração.

Esse poder desempenhado de maneira obrigatória pela autoridade julgadora é ensinado por Hely Lopes Meireles (1995, p. 416):

A responsabilização dos servidores públicos é dever genérico da Administração $e$ específico de todo chefe, e em relação a seus subordinados. No campo do direito administrativo, esse dever de responsabilização foi erigido em obrigação legal e mais que isso em crime funcional, quando relegado pelo superior hierárquico, assumindo a forma de condescendência criminosa (art. 320, CP). $E$, sobejam razões para esse rigor, uma vez que tanto lesa a Administração a infração do subordinado como a tolerância do chefe pela falta cometida, o que é um estímulo para o cometimento de novas infrações.

Ressalta-se, que a sindicância é reservada a casos de infrações que sejam pela pena de advertência e suspensão em até 30 dias. Por essa razão, a legislação conferiu maior flexibilidadeao trâmite da sindicância, ao deixar de impor um rito específico, de maneira que a fluência desse meio apuratório não se reveste de maiores formalidades, em virtude da menor gravidade da infração. A única garantia é que seja admitida a ampla defesa. 
Já o PAD presta-se de investigações a um desvalor de maior gravidade, cuja finalidade está positivada no artigo 148 da Lei no 8.112/1990 com prestígio também, a ampla defesa. É conduzido por uma comissão, cuja composição é de três servidores estáveis, regulada pelo artigo 149 do mesmo diploma legal. Seja como for, a Lei supracitada somente regula esses dois instrumentos apuratórios (PAD e sindicância), que garantem a ampla defesa, ao cabo das quais, se comprovadas à autoria e a materialidade da infração, poderá ser infligida punição.

Sucede que, amiúde, a suspeita de irregularidades no serviço público chega à maior parte das vezes à autoridade administrativa, sem o mínimo de suporte indiciário ou probatório capaz de sustentar a instauração da sindicância ou PAD. Em tais situações de insuficiência probatórias, não se deve abrir quaisquer um dos procedimentos supramencionados de forma precipitada.

É nessa esteira que a Administração Pública, ao deparar-se com representações ou com suspeitas de irregularidades desacompanhadas do mínimo acervo indiciárioprobatório, deverá servir-se de diligências preliminares como a sindicância investigativa, investigação prévia e instrução preliminar (BRASIL, 2012a). Segundo Daniela Figueira (2013), esses podem ser considerados meros instrumentos apuratórios internos da Administração, plenamente admitidos para em razão da inexistência de um mínimo de respaldo indiciário, a fim de poupar os servidores dos efeitos que podem ser danosos a sua imagem de uma errônea instauração de sindicância ou PAD.

Apurada a falta, é importante ressaltar que não há observância do perdão tácito pela indisponibilidade do interesse público, pois os bens tutelados pela Administração Pública, ou seja, seu patrimônio é pertencente a toda coletividade.

A esse respeito, cumpre registrar que a Assessoria Jurídica da Controladoria-Geral da União já manifestou seu entendimento convergente ao aqui exposto (CGU, 2007):

$$
\begin{aligned}
& \text { “O instituto do perdão } \\
& \text { tácito incide quando o } \\
& \text { empregador, não aplica, } \\
& \text { assim que tenha } \\
& \text { conhecimento dos fatos, } \\
& \text { a punição devida ao }
\end{aligned}
$$

empregado faltoso. No caso, a Administração Pública não pode fazer incidir o instituto do perdão tácito após transcorrido o prazo de imediatidade, seja ele qual for. Sabe-se, nesse ponto, que a apuração da irregularidade, e sendo o caso a aplicação da penalidade, constitui evidentemente

manifestação do interesse público consubstanciado na necessidade de se averiguar todos os fatos supostamente irregulares e, se constatada autoria e materialidade suficientes, de se aplicar a penalidade cabível, afastando os quadros da Administração 0 empregado faltoso."

No mesmo sentido, leciona o Ministro Maurício Godinho Delgado (2019, p.831):

A quantificação do prazo tido como razoável a mediar a falta e a punição não é efetuada expressamente pela legislação. Algumas regras, contudo, podem ser alinhavadas. Em primeiro lugar, tal prazo conta-se não exatamente do fato irregular ocorrido, mas do instante de seu conhecimento pelo empregador (ou seus prepostos interempresariais). Em segundo lugar, esse prazo pode ampliar-se ou reduzir-se em função da existência (ou não) de algum procedimento administrativo prévio à efetiva consumação da punição. Se houver instalação de comissão de sindicância para apuração dos fatos envolventes à irregularidade detectada, por exemplo, 
obviamente que disso resulta um alargamento do prazo para consumação da penalidade, já que o próprio conhecimento pleno do fato, sua autoria, culpa ou dolo incidentes, tudo irá concretizar-se apenas depois dos resultados da sindicância efetivada.

Assim, não pode a Administração Pública, na qualidade de empregadora, "perdoar" faltas funcionais praticadas por seus empregados públicos.

\section{PRAZO PRESCRICIONAL}

Caso a Administração Pública demore muito tempo para apurar uma falta cometida pelo servidor, essa perderá o direito de punir, ou seja, ocorrerá a prescrição. A prescrição da pretensão punitiva é um direito fundamental do ser humano e está baseado na segurança jurídica.

O artigo 142 da Lei no 8.112/90 (BRASIL, 1990) prevê os prazos de prescrição disciplinar:

Art. 142. A ação disciplinar prescreverá:

I - em 5 (cinco) anos, quanto às infrações puníveis com demissão, cassação de aposentadoria ou disponibilidade e destituição de cargo em comissão;

II - em 2 (dois) anos, quanto à suspensão; III - em 180 (cento e oitenta) dias, quanto à advertência. (...)

$\S 2$ o Os prazos de prescrição previstos na lei penal, aplicam-se às infrações disciplinares capituladas também como crime.

O termo inicial para a contagem dos prazos supra, sob pena de prescrição, inicia-se na data em que o fato se tornou conhecido pela autoridade administrativa, nos termos do $\S 1$ o do mesmo artigo.

Esse tema é também objeto de um enunciado do Superior Tribunal de Justiça, no
635 (BRASIL, 2019b):

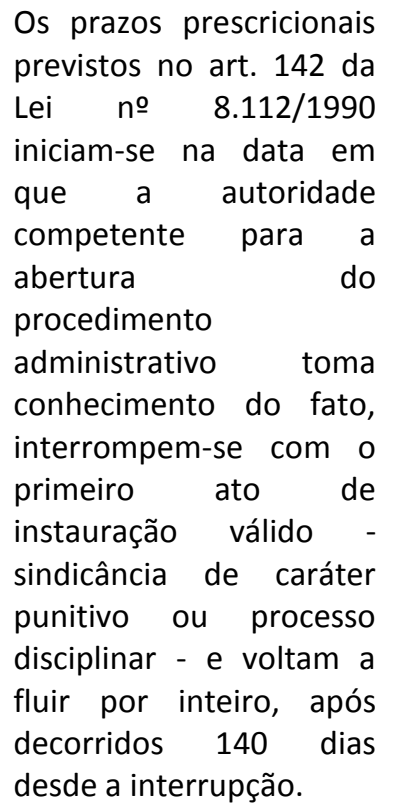

Ademais, a instauração da sindicância ou PAD interrompe, ou seja, zera o prazo prescricional. Assim, quando ele voltar a correr, o prazo comerá desde o início. Porém, o prazo nãopoderá ficar interrompido eternamente.

Para evitar que a Administração demore demais para decidir, em desvantagem para o servidor acusado, o egrégio Superior Tribunal de Justiça em consonância com o mesmo entendimento do Supremo Tribunal Federal, editou o informativo de no 649, (BRASIL, 2019a), que o prazo ficará interrompido no período de 140 dias, correspondente ao prazo máximo, formal, para a conclusão e julgamento do PAD (60 dias, prorrogáveis por mais 60; e mais 20 dias para julgamento), pela previsão nos artigos 152 e 167 da Lei no 8.112/90 (BRASIL, 1990). Também devem ser observados no PAD e na sindicância, os princípios da proporcionalidade e o da razoabilidade entre a punição e a prática do ato infracional.

Nesse sentido, o egrégio Supremo Tribunal Federal (BRASIL, 2012b), já se manifestou em casos análogos: "Essa situação mostra intolerável desprezo ao princípio da proporcionalidade entre o erro praticado e a sanção punitiva, bem como afronta ao princípio a razoabilidade tantas vezes aceito como causa de nulidade de atos administrativos pelos atos anteriores."

A autoridade competente para promover a averiguação dos ilícitos deve ter o discernimento de verificar se são de sindicância 
ou de PAD. Como já citado alhures, a sindicância não precede necessariamente o processo disciplinar; de tal sorte que a autoridade processante deve ficar atenta à natureza da falta e as consequências advindas: se advertência, suspensão de até trinta dias ou a de penalidade mais grave.

A ação investigatória, por sua vez, resulta no arquivamento do processo; na aplicação de penalidades (advertência ou suspensão de até 30 dias); e se couber, a instauração do PAD (CGU, 2019, p.58).

O prazo para a conclusão do referido procedimento administrativo, não excederá 30 dias, podendo ser objeto de prorrogação por igual período de tempo, até mesmo em virtude do disposto no §1으 do artigo 169 da Lei no 8.112/90: "o julgamento fora do prazo não implicanulidade do processo" (BRASIL, 1990).

De forma subsequente, analisa-se a investigação e a depender do resultado, surge a necessidade de instaurar o denominado Processo Administrativo Disciplinar, objetivando apurar de forma profunda, a responsabilidade do servidor devido à realização de possível infração praticada no exercício de sua atribuição, ou que tenha relações com as atribuições do cargo em que se encontre investido.

Os autos da sindicância integrarão o processo administrativo como peça informativa da instrução, podendo ser repetidos, ainda que mediante mera ratificação, os depoimentos indispensáveis à elucidação dos fatos, conforme artigo 154 do mesmo diploma legal. Ademais, como medida cautelar e a fim de que o servidor não venha a influir na apuração da irregularidade, a autoridade instauradora do processo disciplinar poderá determinar o seu afastamento do exercício do cargo, pelo prazo de até 60 (sessenta) dias, sem prejuízo da remuneração.

Poderá o afastamento ser prorrogado por igual período, findo o qual cessarão os seus efeitos, ainda que não concluído o processo, conforme artigo 147, caput e parágrafo único do aludido diploma legal. Sendo assim, tem-se como razoável a conclusão de que a medida preventiva compulsória há de ser adotada imediatamente após a instauração do processo.

Na hipótese que a lei a faculta, como se verifica ao entendimento majoritário da doutrina de Mauro Roberto Gomes de Mattos (2012), a autoridade competente para efetivá- la, deve considerar os acontecimentos e as circunstâncias em que o apuratório será desenvolvido e a ascendência do servidor envolvido aos meios de prova, às testemunhas e ao próprio colegiado, a fim de avaliar a conveniência de determinar o afastamento, de imediato, ou de preservar a prestação de serviços. A última alternativa não impede que, no curso da instrução, seja ordenado o afastamento facultativo, caso se constate o risco de influência.

A instauração do PAD dar-se-á mediante publicação de portaria baixada pela autoridade competente, que designará seus integrantes e indicará dentre eles, o presidente da comissão de inquérito. Nesse sentido, a Súmula 641 do egrégio Superior Tribunal de Justiça, (BRASIL, 2020), expôs que a portaria de instauração do processo administrativo disciplinar prescinde da exposição detalhada dos fatos a serem apurados. Ademais, a convocação por parte da autoridade competente, para servidor integrar comissões disciplinares é encargo obrigatório e a princípio irrecusável, teoricamente independente de prévia autorização de superior imediato do servidor convocado. Na prática, nada impede que haja um prévio acerto entre as autoridades envolvidas. Ressalte-se apenas que, se, excepcionalmente for necessário designar servidor de outro órgão público, convém prévia solicitação ao titular daquele órgão.

Com base no artigo 150 da lei referida, a Comissão exercerá suas atividades com independência e imparcialidade, assegurando o sigilo necessário à elucidação do fato ou exigido pelo interesse da administração, obtendo, por via de regra, caráter reservado. Apropriado ressaltar que a autoridade julgadora não está adstrita às conclusões da Comissão de Inquérito, mas deve fundamentar suas decisões nas provas colhidas por ela e não por outros motivos que não ficaram provados, em respeito às garantias constitucionais.

O prazo para a conclusão do processo não poderá exceder 60 dias, que será contado a partir da data de publicação, permitindo sua prorrogação por igual período, quando as circunstâncias o exigirem. Se praticados com observância de normas processuais, os atos da comissão de inquérito que não logrou concluir a apuração do prazo legal são válidos e suscetíveis de aproveitamento pelo colegiado posterior, dependendo de seu conteúdo e do juízo de 
valor da nova comissão de julgamento.

De qualquer forma, a perda do prazo de sessenta dias também não invalida o procedimento disciplinar, em face do já disposto artigo 169, §1으 da Lei no 8112/1990 (BRASIL, 1990). Com base no artigo 161 do mesmo diploma legal, quando tipificada a infração disciplinar, será formulada a indiciação do servidor, com a especificação dos fatos a ele imputados e das respectivas provas. Apreciada a defesa, a comissão elaborará relatório minucioso, onde resumirá as peças principais dos autos e mencionará as provas em que se baseou para formar sua convicção. Reconhecida a responsabilidade do servidor, a comissão indicará o dispositivo legal ou regulamentar transgredido, bem como as circunstâncias agravantes e atenuantes. $\mathrm{Na}$ hipótese do PAD ter-se originado de sindicância cujo relatório conclua que o fato está previsto como ilícito penal, a autoridade competente (instauradora) encaminhará cópia dos autos ao Ministério Público, independente da imediata instauração do processo disciplinar.

A comissão processante dará conhecimento, ao Ministério Público e ao Tribunal de Contas da União, da instauração do procedimento administrativo para apurar a prática do ato de improbidade referente à Lei no 8.429/1992 (BRASIL, 1992), que importe em enriquecimento ilícito (artigo 9ㅇ), prejuízo ao erário (artigo 10) e atente contra os princípios da administração Pública (artigo 11).

Havendo fundados indícios de responsabilidade por ato de improbidade, a comissão representará ao Ministério Público ou a procuradoria do órgão para que requeira ao juízo competente a decretação de sequestro dos bens do agente ou terceiro que tenha enriquecido ilicitamente ou causado danos ao patrimônio público. Ademais, na hipótese de enviar os autos para Justiça Comum para apurar ilícitos penais, a absolvição na seara criminal interfere no resultado do processo administrativo disciplinar apenas quando for reconhecida a efetiva inexistência do fato ou da autoria, conforme observa Bacellar Filho (2013). Isso decorre do sistema de jurisdição única, adotado pelo Brasil, de acordo com o qual só o Poder Judiciário pode decidir em caráter de definitividade. No que tange à prescrição, pela redação do citado $\S 20$ do art. 142 da Lei no 8.112/90 (BRASIL, 1990), se o servidor público cometeu infração disciplinar que também é tipificada como crime, o prazo prescricional para apuração desta infração administrativa não será o estipulado pela lei supra, mas sim, o prazo prescricional previsto no artigo 109 do Código Penal (BRASIL, 1940) para aquele respectivo crime.

Esse entendimento está baseado na independência das esferas administrativa e criminal. Em razão dessa independência de instâncias, a existência de apuração criminal não pode ser um pré-requisito para a utilização do prazo prescricional penal, para salvaguardar a segurança jurídica se o prazo prescricional da infração administrativa fosse "decidido" com base na existência ou não da apuração criminal.

Vale ressaltar, esse é o entendimento do egrégio Supremo Tribunal Federal (BRASIL, 2018):

(...) LEGITIMIDADE DA APLICAÇÃO DO PRAZO PRESCRICIONAL DA LEI PENAL, INDEPENDENTEMENTE, DE INSTAURAÇÃO DE PROCEDIMENTO NA ESFERA CRIMINAL. (...) STF. 1a Turma. MS 35631 ED/DF, Rel. Min. Alexandre de Moraes, DJe 22/11/2018. (...). Capitulada a infração administrativa como crime, o prazo prescricional da respectiva ação disciplinar tem por parâmetro o estabelecido na lei penal (art. 109 do CP), conforme determina 0 art. $142, \S 2$ 으, da Lei no 8.112/1990,

independentemente da instauração de ação penal. (...)

O processo disciplinar, com o relatório da comissão, será remetido à autoridade que determinou a sua instauração para julgamento e no prazo de 20 dias, contados do recebimento do processo, a autoridade julgadora proferirá a 
sua decisão.

O julgamento fora deste prazo legal também não implicaria nulidade do processo, desde que haja observância do prazo citado alhures de no máximo 140 (cento e quarenta) dias, para não causar insegurança jurídica àqueles funcionários que ficam à mercê do julgamento dos procedimentos administrativos.

O princípio da segurança jurídica é inerente ao próprio Estado de Direito (art. 1으, CF), consoante às lições de Humberto Theodoro Júnior (2006), que agrega a esse valor, os valores de liberdade, bem-estar, igualdade e justiça, numa categoria de 'valores supremos de uma sociedade fraterna, pluralista e sem preconceitos, fundada na harmonia social. " (THEODORO JÚNIOR, 2006, p. 97).

\section{ACUMULAÇÃO DE CARGOS}

Deve ser ressaltado outra questão muito comum acerca dos servidores públicos ocuparem mais de um cargo na Administração Pública. Em regra, a acumulação remunerada de cargos públicos é vedada pela Constituição, que em seu artigo 37, inciso XVI, alíneas " $a$ ", "b" e "c", admitem três exceções.

São estas a acumulação de dois cargos de professor, de um cargo de professor com outro técnico ou científico, ou ainda de dois cargos ou empregos privativos de profissionais de saúde, com profissões regulamentadas. Dessa forma, a acumulação de cargos públicos fora das hipóteses admissíveis configura, em tese, conduta que atentam contra os princípios da Administração Pública e, consequentemente, enquadrada como ato de improbidade administrativa, nos termos do artigo 11, caput, da Lei 8.429/92 (BRASIL, 1992).

Pois bem, se o funcionário que acumular cargos públicos cometer uma falta grave em uma função se estenderia a outra? Para responder a esse questionamento, é cediço enfocar que a punição do funcionário faltoso, antes de ser um castigo, é principalmente o meio de que se vale a Administração para restabelecer a ordem afetada pela infração disciplinar.

A boa ordem dos serviços só pode ser obtida mediante a exemplaridade de comportamento dos funcionários. Violada essa exemplaridade pelo cometimento da falta disciplinar, ofendida é, também, a boa ordem dos serviços que se objetiva restaurar pela punição do infrator. O restabelecimento da boa ordem ora se fará com a expulsão do servidor dos quadros funcionais (demissão), ora se concretizará mediante afastamento temporário das funções que desempenha (suspensão).

Poderá verificar-se, ainda, pela simples repreensão do infrator ou pela aplicação de pena pecuniária (multa). E, para que atinja seu desiderato, é preciso que a expulsão ou o afastamento se estendam a todas as situações funcionais em que se encontre o infrator. $E$ também nas hipóteses de suspensão, aplicada ao servidor em virtude de infração cometida no exercício de um cargo, a penalidade se estenderá ao outro cargo ou função que exerça em regime de acumulação.

O afastamento imposto pela suspensão é o meio de que se vale a Administração para restabelecer a boa ordem dos serviços públicos, violada pelo procedimento faltoso do funcionário. Esse afastamento só atingirá seus objetivos na medida em que a perda pecuniária sofrida pelo servidor, relativa aos dias em que deixar de trabalhar por força da suspensão, poder convencê-lo de que não vale a pena incidir em nova falta. Esse desiderato não seria perfeitamente conseguido se a suspensão se limitasse ao cargo ou função em cujo exercício foi cometido a infração disciplinar, deixando de estender-se ao cargo exercido em acumulação.

Nesse sentido, a Procuradoria do Estado de São Paulo já se manifestou (SÃO PAULO, 1977): Cargo Público exercido em acumulação regular. Efeitos:

1. A Pena Demissória agravada com a nota: "A Bem do Serviço Público", na hipótese de o servidor exercer em regime de acumulação regular outro cargo público, acarreta a perda de ambos;

2. A Pena Demissória Simples, nas mesmas circunstâncias, acarretará a perda de ambos, caso, através de exame da natureza ou espécie da falta disciplinar cometida, reconheçase a incompatibilidade do servidor para o exercício de cargos públicos;

3. Salvo o disposto no item seguinte, os efeitos das penas corretivas, todavia, devem permanecer adstritos ao cargo em que foi cometida a falta;

4. A Pena Disciplinar pode ser aplicada ao servidor que, no exercício de outro cargo, função ou atividade, transgrida deveres impostos pela subordinação hierárquica. 
Pois bem, na caracterização de abordagens e levantamentos realizados para a formalização do estudo, é considerável dissertar os principais pontos e aspectos que nortearam a junção de ideias, correlacionadas com a vivência social do citado tema. A despeito dos instrumentos processuais, observou-se que a instauração do processo administrativo independente de sindicância, deve ser considerado um instrumento apuratório autônomo quando haver confissão lógica ou quando evidentes a autoria e materialidade da infração.

Ademais, devem ser observados os princípios da proporcionalidade e da razoabilidade entre a prática e a punição do ato infracional, de modo a respeitar os desígnios constitucionais.

No que tange à acumulação de cargos concernentes aos servidores públicos, é cediço enfocar que a punição do funcionário faltoso, antes de ser um castigo é principalmente, o meio de que se vale a Administração para restabelecer a ordem afetada pela infração disciplinar, fazendo- se-pois a suspensão ou expulsão dos servidores, estendendo-se para todos os cargos que os servidores se encontrem vinculados e envolvidos. Desse modo, é possível a acumulação de dois cargos no caso de: Professores, de um cargo de professor com outro técnico/científico, ou aindade dois cargos ou empregos privativos de profissionais de saúde.

Em última instância, denota-se o instituto concernente aos prazos prescricionais com o intuito de promover a boa ordem processual e, para tanto, proporcional, visto que a prescrição da pretensão punitiva é um direito fundamental de todos.

Assim, o termo inicial para a contagem dos prazos prescricionais possui como início a data em que o fato se tornou conhecido pela autoridade administrativa competente, de acordo com o entendimento de VENOSA (2002). Podendo esse prazo ainda ser suspenso ou interrompido, a depender dos casos previstos nos artigos da Lei supracitada.

\section{CONSIDERAÇÕES FINAIS}

Em detrimento dos estudos e análises realizadas e, em conformidade com os aspectos da Administração Pública, foi possível obter por desígnio que o dever dos gestores públicos em apurar as infrações disciplinares, transcende a mera abertura do procedimento administrativo adequado. Isso porque além de estarem associados à gestão pública pelo dever de conciliar o interesse público de ter trabalhadores dignos e probos vinculados à Administração com o interesse privado desses trabalhadores provarem sua eventual inocência, o operador administrativo deve guardar uma conduta em observância aos princípios constitucionais e a eficiência, na abertura e julgamentos de procedimentos desnecessários.

Ao que concerne à indisponibilidade do perdão tácito, finaliza-se que não pode a Administração Pública na qualidade de empregadora, desonerar faltas funcionais praticadas por seus servidores, ainda que seja de enorme qualidade sua expressão trabalhista. Ademais, caso a Administração Pública demore muito tempo para apurar uma falta cometida pelo servidor, essa, perderá o direito de punir, ocorrendo a prescrição da pretensão punitiva, caracterizado como direito indeclinável para com todos. No entanto, é admissível que a autoridade hierárquica competente abra procedimentos que não se tenham fortes indícios de transgressões disciplinares, em face do Direito Administrativo dialogar com os princípios, direitos e garantias descritos na Constituição Federal de 1988 (BRASIL, 1988).

É importante enfatizar que esse é o entendimento que mais se coaduna com o Estado Democrático de Direito. Assim, denota a relevância em saber qual o procedimento disciplinar cabível e adequado à punição de servidores infratores, inclusive aqueles que acumulam cargos públicos (estendendo-se a penalidade para os cargos seguintes do ocupante) sendo imperativo próprio do devido processo legal e a efetiva operosidade dos meios e recursos garantidores dos direitos fundamentais, mormente contraditório, ampla defesa e inadmissibilidade do uso no processo de provas obtidas ilicitamente.

À vista disso, ainda que haja previsão normativa acerca da obrigatoriedade de o agente público abrir o procedimento disciplinar adequado a partir da ciência da irregularidade cometida, a hermenêutica resultante promove, por fim, a abertura somente quando embasado elementos que tornem imprescindíveis sua continuidade e sua finalização útil, a fim de satisfazer as pretensões e os desideratos da Administração, ansiando a boa ordem e a 
vivência do meio social.

\section{REFERÊNCIAS}

BACELLAR FILHO, Romeu Felipe. Processo administrativo disciplinar. 4.ed. São Paulo: Saraiva, 2013, p. 112.

BRASIL. A responsabilização do servidor nos atos de improbidade e ilícitos penais bem como os efeitos no cargo público. 05 de fevereiro de 2018. Disponível em: https://www.blogservidorlegal.com.br/responsa bilizacao-do-servidornos-atos-de-improbidadee-ilicitos-penais-bem-como-os-efeitos-no-cargopublico/. Acesso em: 21 fev. 2020.

BRASIL. Constituição (1988). Constituição da República Federativa do Brasil. Brasília: Senado Federal, 1988.

BRASIL. Decreto-Lei no 2.848, de 07 de dezembro de 1940. Código Penal. Disponível em:

https://www2.camara.leg.br/legin/fed/declei/19 40-1949/decreto-lei-2848-7-dezembro-1940-

412868-publicacaooriginal-1-pe.html. Acesso em: 28 jun. 2020.

BRASIL. Normas Legais. Disponível em: http://www.normaslegais.com.br/ Acesso em: 21 fev. 2020.

BRASIL. Sindicância Administrativa. Regina Napoleão. 27 de outubro de 2012a. Disponível em:

https://www2.unesp.br/portal\#!/cppavo/ro teiro-de-abertura-de-

procedimento/apuracao-preliminar-/ Acesso em: 21 fev. 2020.

BRASIL. Superior Tribunal de Justiça. Súmula 641 que trata que a portaria de instauração do processo administrativo disciplinar prescinde da exposição detalhada dos fatos a serem apurados. Benefícios fiscais e processo administrativo disciplinar. 19 de fevereiro de 2020. Diário da Justiça Eletrônico. Disponível em:

http://www.sti.jus.br/sites/portalp/Paginas/Co municação/Noticias/Primeira- Secaoaprovasumulas-sobre-benefícios-fiscais-eprocesso-administrativo-disciplinar.aspx. Acesso em: 21 fev. 2020.
BRASIL. Superior Tribunal de Justiça. Informativo 649. 20 de agosto de 2019. Diário da Justiça Eletrônico. Disponível em: https://www.dizerodireito.com.br/2019/08/info rmativo-comentado- 649-stj.html. Acesso em: 21 fev. 2020.

BRASIL. Superior Tribunal de Justiça. Súmula 635. 14 de junho de 2019. Diário da Justiça Eletrônico. Brasília, 2019. Disponível em: https://www.stj.jus.br/internet_docs/bibliot eca/clippinglegislacao/Sumula_633,634_201 9_primeira_secao.pdf. Acesso em: $21 \mathrm{fev}$. 2020.

BRASIL. Superior Tribunal de Justiça. Súmula 641. 19 de fevereiro de 2020. Diário da Justiça Eletrônico. Disponível em: http://www.stj.jus.br/docs internet/VerbetesST J.pdf. Acesso em: 21 fev. 2020.

BRASIL. Supremo Tribunal Federal. A G. Reg. no Agravo de Instrumento $\mathbf{7 8 0 . 9 5 0}$ Ceará. Agravo Regimental em Agravo de Instrumento. Administrativo. Servidor Público. Estado Do Ceará. Demissão. Proporcionalidade Da Pena. Enunciados 279 e 280 da Súmula/STF. A. G. Reg. Agravo De Instrumento 780.950 Ceará. Brasília, 6 de março de 2012b. Disponível em: https://redir.stf.jus.br/paginadorpub/paginador. jsp?docTP=TP\&doclD=1830719 Acesso em: 21 fev.2020.

BRASIL. Supremo Tribunal Federal. Legitimidade da aplicação do prazo prescricional da Lei Penal, independentemente, de Instauração de Procedimento na Esfera Criminal. (...) 1 1 a Turma. MS 35631 ED/DF, Rel. Min. Alexandre de Moraes. Brasília, 05 de dezembro de 2018. Disponível em: https://stf.jusbrasil.com.br/jurisprudencia/6617 91722/mandado-de-seguranca-ms-35631-dfdistrito-federal. Acesso em: 21 fev. 2020.

BRASIL. Lei no 8.429, de 02 de junho de 1992. Dispõe sobre as sanções aplicáveis aos agentes públicos nos casos de enriquecimento ilícito no exercício de mandato, cargo, emprego ou função na administração pública direta, indireta ou fundacional e da outras providências. Diário Oficial da União, 02 de junho de 1992. Rio de Janeiro, 1992. Disponível em: https://www2.camara.leg.br/legin/fed/lei/1992 
Llei- 8429-2- junho-1992-357452-norma-pl.html Acesso em: 03 fev. 2020.

Lei no 6.766, de 19 de dezembro de 1979. Dispõe sobre o parcelamento do solo urbano. DOU de

19 de dezembro de 1979. Disponível em: http://www.planalto.gov.br/ccivil_03/leis/16 766.htm. Acesso em: 03 fev. 2020.

Lei no 8.112, de 11 de dezembro de 1990 . Dispõe sobre o regime jurídico dos servidores públicos civis da União, das autarquias e das fundações públicas federais. DOU de 12 de dezembro de 1990. Disponível em: http://www.planalto.gov.br/ccivil 03/leis/18112 cons.htm. Acesso em: 03 fev. 2020.

Lei no 9.784, de 29 de janeiro de 1999. Regula o processo administrativo no âmbito da Administração Pública Federal. DOU de 1 de fevereiro de 1999. Disponível em: http://www.planalto.gov.br/ccivil_03/leis/19 784.htm\#: :text=Regula\%20o\%20processo\% 20administrativo\%20no\%20\%C3\%A2mbito\% 20da\%20Administra\%C3\%A7\%C3\%A3०\%20P \%C3\%BAblica\%20Federal.\&text=Art.,cumpri mento\%20dos\%20fins\%20da\%20Administra \%C3\%A7\%C3\%A3o. Acesso em: 03 fev. 2020.

DELGADO, Maurício Godinho. Curso de Direito do Trabalho. 18. ed. São Paulo: LTr, 2019. p. 831.

FIGUEIRA, Daniela. Diretrizes para o Assessoramento Jurídico em Matéria Disciplinar. 1. ed. Brasília: AGU, 2013. Disponível em: https://redeagu.agu.gov.br/. Acesso em: 21 fev. 2020.

GIL, Antônio Carlos. Métodos e Técnicas de Pesquisa Social. 6. ed. São Paulo: Atlas, 2008.

LIMA, B. J. MENEZES. Sindicância e verdade sabida. 2. ed. São Paulo: Prol, 1994, p. 55.

MATTOS, Mauro Roberto Gomes. Lei no 8.112/90: interpretada e comentada. 6. ed. São Paulo: Editora Impetus, 2012.

MEIRELES, Hely Lopes. Direito Administrativo Brasileiro. 20. ed. São Paulo: Malheiros, 1995. p. 416.
MELLO, Celso Antônio Bandeira de. Curso de direito administrativo. 27. ed. São Paulo: Malheiros, 2014. p. 979.

MINAYO, Maria Cecília de Souza (org.). Pesquisa social: teoria, método e criatividade. 29. ed. Petrópolis, RJ: Vozes, 2010. p. 80.

SÃO PAULO (Estado). Procuradoria Geral do Estado de São Paulo. Cargo Público exercido em acumulação regular. Efeitos. Relatório ao Parecer no 116 de 1977. São Paulo, 1978. Disponível em: http://www.pge.sp.gov.br/centrodeestudos/bibl iotecavirtual/sumulas/sumula13.htm. Acesso em: 21 fev. 2020.

THEODORO JÚNIOR, Humberto. Onda Reformista do Direito Positivo e suas Implicações com o Princípio da Segurança Jurídica. Revista da Escola Nacional de Magistratura, n. 1, abr. 2006, p. 97.

UNIÃO, Controladoria Geral. Assessoria Jurídica. Relatório ao Parecer no 2987/2007. Perdão Tácito.

Disponível em: https://repositorio.cgu.gov.br/bitstream/1/ 46026/8/Manual de Estatais 2020.pdf. Acesso em: 21 fev. 2020.

UNIÃO, Controladoria Geral. Manual de Processo Administrativo Disciplinar. Brasil, maio.2019.

Disponível em: https://www.justica.gov.br/coger/arquivos/man ual pad mai-2019.pdf. Acesso em: 21 fev. 2020.

VENOSA, Sílvio de Salvo. Direito Civil. 2 ed. São Paulo: Atlas, 2002. p. 152. v. 1. 